\title{
KOREA SELATAN DAN PROVOKASI KOREA UTARA: TAKTIK PENGARUH DAN PERSUASI PADA MASA PEMERINTAHAN LEE MYUNG BAK
}

\author{
Arfin Sudirman \\ Departemen Hubungan Internasional Universitas Padjadjaran Indonesia \\ Email: arfin.sudirman@unpad.ac.id
}

\begin{abstract}
ABSTRAK
Korea Selatan memiliki berbagai kepentingan dan telah menetapkan tujuan-tujuan dalam kebijakan luar negerinya. Namun upaya pencapaian kepentingan dan tujuan tersebut, terutama berkenaan dengan stabilitas di Semenanjung, seringkali dihadapkan pada tantangan, Aksi-Aksi provokatif dari Korea Utara merupakan salah satu isu yang serius dan perilaku yang tidak diinginkan oleh Korea Selatan. Oleh karena itu Korea Selatan melakukan sejumlah kebijakan luar negeri dalam upayanya untuk mencegah aksi provokatif dari Korea Utara, yang dalam penelitian ini difokuskan pada periode tiga tahun pertama pemerintahan Lee Myung Bak tahun 2008 hingga 2010. Dengan menggunakan metode kualitatif deksriptif analitis, artikel ini mencoba untuk mengidentifikasi kebijakan luar negeri Korea Selatan dalam mencegah aksi provokasi dari Korea Utara. Artikel menunjukkan bahwa Korea Selatan menggunakan taktik pengaruh untuk mencegah provokasi Korea Utara dan memanfaatkan kapabilitas ekonominya untuk mendukung kebijakan tersebut. Adapun penggunaan taktik pengaruh oleh Korea Selatan tersebut bergantung pada kasus dan tingkat aksi provokasi Korea Utara, mulai dari penggunaan taktik persuasi hingga penalti hukuman non-kekerasan, termasuk di dalamnya penggunaan taktik kekerasan secara terbatas ketika aksi provokasi tidak dapat dihentikan dan cegah dengan taktik lain.
\end{abstract}

Kata kunci: Kebijakan Luar Negeri, Aksi, Provokasi, Republik Korea, Republik Demokrasi Rakyat Korea

\section{SOUTH KOREA AND NORTH KOREA'S PROVOCATION: TACTICS OF INFLUENCE AND PERSUATION DURING LEE MYUNG BAK'S PRESIDENCY}

\begin{abstract}
South Korea has various national interests in its foreign policy. However, in an attempt to achieve their national interests, particularly in regard to the stability in the Korean Peninsula, is often confronted with challenges, the provocative acts by the North Korea. It has been considered as one of the most undesirable and serious issues for South Korea. Therefore, South Korea has imposed a number of foreign policy to prevent the provocative action conducted by the North Korea, which in this paper focused on the first three years of Lee Myung Bak's administration in 2008 to 2010. The objective of this paper is to identify Korean foreign policy South in preventing North Korea's provocative action. By using descrpitive analitive qualitative methods This article shows that South Korea had been using influential tactics to prevent North Korean provocative actions and utilizing its economic capabilities to support the policy. The use of South Korean influence tactics depends on the case and extent of North Korean provocative action, ranging from persuasion tactics to non-violent penalty penalties, including the use of limited tactics of violence when provocative action is unstopabble by other tactics.
\end{abstract}

Key words: Foreign Policy, Action, Provocation, Republic of Korea, Democratic People’s Republic of Korea

\section{PENDAHULUAN}

Hubungan inter-Korea pasca berhentinya perang Korea pada tahun 1953 selalu mengalami pasang surut. Perbedaan mendasar dalam kebijakan luar negeri masing-masing negara tersebut, yakni Korea Utara dengan paham sosialisnya (ideologi Juche atau self-realiance) dan Korea Selatan yang menganut paham demokrasi liberal, menjadikan kepentingan dan tujuan dari masing-masing negara tersebut hampir selalu bertentangan. Aksi-aksi provokasi salah satunya merupakan isu yang menyebabkan naik turunnya stabilitas perdamaian dan keamanan di Semenanjung Korea dan tentunya mengancaman pula kepentingan Korea Selatan didalamnya.

Aksi provokatif yang telah dilakukan oleh Korea Utara sepanjang tahun 1953 hingga hari ini memiliki beragam bentuk mulai dari percobaan pembunuhan pemimpin Korea Selatan, terror bom, penculikan warga sipil, 
provokasi militer di perbatasan, uji coba misil hingga program pengembangan senjata nuklir. Beberapa diantaranya adalah percobaan pembunuhan presiden Park Chung Hee (21 januari 1968), pemboman di Burma (Vietnam) yang membunuh empat menteri dan 16 orang Korea Selatans lainnya (9 oktober 1983), pengeboman pesawat (South Korea Airline) yang membunuh 115 orang didalamnya (29 nopember 1987), pertempuran Yeopyeong (1999 dan 2002), percobaan nuklir (Oktober 2006) dan sebagainya.

Perilaku-perilaku provokatif dari Korea Utara tersebut merupakan perilaku yang tidak diinginkan dan mengancam kepentingan dan tujuan kebijakan luar negeri Korea Selatan. Oleh karena itu, Korea Selatan tentunya melakukan sejumlah aksi untuk menjalankan pengaruhnya untuk mencegah eskalasi konflik dan aksi provokasi dari Korea Utara.

Terdapat beberapa penelitian terdahulu yang mengeksplorasi mengenai isu reunifikasi Semenanjung Korea. Sebagai contohnyaAstrom (2013) menggunakan kerangka teoritikal konstruktivisme sosial untuk menganalisis dampak dari kebijakan luar negeri Korea Selatan yang berbeda terhadap Korea Utara dengan melihat beberapa peristiwa penting seperti krisis nuklir korea pertama, krisis nuklir Korea kedua, serta tenggelamnya kapal perang Cheonan dan penyerangan artileri ke pulau Yeonpyeong oleh Korea Utara. Kemudian Nack Kim (2011) membahas mengenai hubungan inter-Korea sejak dimulainya pemerintahan Lee Myung Bak pada febuari 2008 hingga 2011 dengan menganalisis kebijakan Lee Myung Bak terhadap Korea Utara dengan memperhatikan faktor-faktor seperti kondisi kesehatan Kim Jong Il uji coba misil dan nuklir Korea Utara, insiden Cheonan dan Yeonpyeong seta analisis terhadap berbagai kebijakan serta respon kebijakan didalamnya.

Selain itu, terdapat penelitian lain yang dilakukan oleh Konishi (2011) yang merupakan hasil kolaborasi dari IFPA, Institute of Foreign Affairs and National Security (IFANS) dan US Institute of Peace (UIP) yang melibatkan sekitar 50 pembuat kebijakan dan ahli dari Amerika Serikat, Tiongkok dan Korea Selatan untuk mediskusikan secara mendalam berkenaan dengan situasi keamanan terkini di dalam dan lingkungan sekitar semenanjung korea dan prospek bagi kerjasama diantara ketiga negara; dampak dari trend proliferasi nuklir dan misil balistik serta prospek rezim damai semenanjung Korea (KPPR) yang didasarkan pada denuklirisasi Korea Utara. Berikutnya adalah penelitian yang dilakukan oleh Fazio (2011) yang menganalisis sifat dasar aktual dari keseluruhan ancaman keamanan Korea Utara, menekankan berbagai sisi komponennya -konvensional, teroris dan nuklir- dan berargumen bahwa bahaya dari Korea Utara adalah meragukan. Artikel ini juga menilai konteks sejarah dari ancaman keamanan Korea Utara dan keberlangsungan dari beberapan pilihan kebijakan yang ada untuk komunitas internasional yang berhadapan dengan Korea Utara. Terakhir adalah penelitian dari Bechtol (2010) yang membahas mengenai tragedi tenggelamnya kapal perang Cheonan Korea Selatan. Penelitian ini menyimpulkan bahwa dampak dari tragedi tersebut akan mengubah taktik, teknik dan prosedur dari Korea Selatan terhadap Korea Utara dan bahwa penahanan perilaku 'nakal' Korea Utara harus menjadi prioritas utama bagi aliansi militer Korea Selatan- Amerika Serikat.

Berbeda dengan penelitian sebelumnya, dalam penelitian ini akan difokuskan pada pendeskripsian aksi kebijakan luar negeri yang dilakukan oleh Korea Selatan dalam upaya mempengaruhi perilaku dan kebijakan dari Korea Utara, yakni berkenaan dengan upaya Korea Selatan dalam mencegah (to deter) aksiaksi provokatif dari Korea Utara.

Peneliti menggunakan kerangka pemikiran dari K.J. Holsti mengenai aksi kebijakan luar negeri, khususnya mengenai bagaimana pengaruh dalam aksi kebijakan luar negeri yang pada umumnya jarang terbahas secara teoritis dalam kajian analisis kebijakan luar negeri.

\section{METODE}

Tulisan ini bertujuan untuk mengidentifikasi taktik persuasi yang dilakukan oleh Korea Selatan dalam mencegah aksi provokasi dari Korea Utara dan sumber daya yang mendukungnya.

Metode yang digunakan peneliti dalam tulisan ini adalah metode penelitian kualitatif deskriptif analisis oleh Robert E. Stake (2010: 11) yang menekankan pada intepretasi peneliti dalam penelitiannya. Hal ini karena fenomena utama yang diamati adalah aksi kebijakan luar 
negeri yang nantinya akan dianalisis secara deskriptif melalui interpretasi yang logis.

Dalamtulisanini,penulismakrointerpretasi untuk mendapatkan penggeneralisasian akan bagaimana sekelompok besar orang bekerja, dalam hal ini adalah elit-elit yang terlibat dalam proses pembuatan kebijakan luar negeri Korea Selatan, dalam mencegah aksi provokatif lebih lanjut dari Korea Utara.

Karena masih terbatasnya kapasitas penulis dalam melakukan interpretasi, penginterpretasian pun dilakukan melalui berbagai kalangan akademisi atau ahli yang memang berfokus terhadap isu kebijakan luar negeri Korea Selatan, keamanan regional ataupun kawasan asia timur. Begitu pula dengan jenis deskripsi dalam metode penelitian sosial, peneliti menggunakan salah satu jenis deskripsi, yakni deskripsi kriteria yang dibutuhkan dalam menjelaskan keakuratan data.

Artikel ini menggunakan kerangka teoritis K. J. Holsti (1995: 117) mengenai aksi kebijakan luar negeri dalam memaknai taktik persuasi Korea Selatan. Jika pada umumnya analisis kebijakan luar negeri berfokus pada analisis tipe tujuan dan kepentingan yang dikejar oleh negara, peran dari berbagai faktor domestik dan sistemik dalam formulasi kebijakan tersebut dan jalan bagaimana sistem internasional mempengaruhi orientasi umum suatu negara terhadap lingkungan eksternalnya, pada analisis ini akan berfokus pada teknik utama yang digunakan oleh negara atau unit politik dalam mencapai atau mempertahankan tujuan, kepentingan dan orientasi dari kebijakan luar negerinya.

Di dalam sistem internasional kontemporer, dimana hampir setiap unit terikat satu sama lain, kebanyakan tujuan domestik dan luar negeri suatu negara tidak dapat dicapai ataupun dipertahankan tanpa mempengaruhi perilaku negara lain. Dengan kata lain, dengan tujuan untuk mencapai atau mempertahankan tujuan-tujuannya, suatu negara harus melakukan sejumlah aksi terhadap pihak lain. Aksi itu sendiri, menurut Holsti, merupakan sebuah bentuk komunikasi yang dimaksudkan untuk mengubah atau mendukung sikap dan perilaku dari pihak lain dimana pemerintah suatu negara- bergantung terhadapnya dalam mencapai tujuan-tujuannya. Adapun berkenaan dengan tujuan kebijakan luar negeri tersebut, menurut Hoslti (1995: 84-108), meliputi:
1). Keamanan, kemampuan negara untuk mempertahan diri, baik itu dengan menurunkan kerentanan, maupun dengan mengurangi persepsi ancaman. Dalam konteks Korea Selatan, tujuan keamanannya yakni stabilitas perdamaian yang bertahan lebih lama yang menekankan kepentingan bersama antara orang Korea dan komunitas internasional dengan menyelesaikan isu nuklir (denuklirisasi) Korea Utara dan trustbuilding dan kerjasama yang lebih efektif yang dilatarbelakangi oleh konsensus dan norma-norma Asia Timur dan komunitas internasional dan membentuk komunitas damai inter-Korea yang di dasarkan pada denuklirisasi.

2). Otonomi, berkaitan dengan kapasitas pemerintah negara untuk menangkal pengaruh, paksaan atau pengaturan oleh entitas politik lain. Berkenaan dengan tujuan ini, Korea Selatan menerapkan prinsip Pragmatisme ${ }^{1}$ Kreatif yang didasarkan pada tiga pilar utama: (1) penilaian keras kepala (hard-headed) dan menyeluruh terhadap lingkungan sekitar; (2) pengembangan rencana aksi spesifikuntuk tujuanyang dapat dicapai; (3) memaksimalkan pengembalian upaya dan biaya yang diinvestasikan, yang ketiganya ditujukan untuk menghindari pemberian bantuan secara unilateral dari Korea Selatan.

3). Kekayaan (Wealth), berkaitan dengan kapasitas negara untuk menciptakan keadilan dan tatanan sosial, memaksimalkan pertumbuhan ekonomi untuk mengurangi pengangguran dan penyediaan berbagai layanan yang dapat membantu meningkatkan kualitas hidup seluruh warga negaranya. Tujuan ini dalam konteks Korea Selatan, yakni: kesejahteraan bersama dengan menekankan pencarian pembangunan tingkat nasional yang lebih stabil dan efisien yang berjalan beriringan dengan pembangunan komunitas internasional dan; Pembangunan komunitas ekonomi Korea yang bertujuan untuk mencapai kemajuan substansial dalam pertukaran dan kerja sama inter-Korea dan bergerak dari pemberian bantuan secara sepihak menuju kerja sama yang saling

Pragmatisme merupakan pemikiran serupa bisnis, misalnya, ketika suatu negara memberikan bantuan atau berinvestasi ke negara lain harus mampu memberikan keuntungan yang sesuai dengan investasi atau bantuan yang mereka berikan. 
menguntungkan.

4). Status dan prestise, berkaitan dengan pencarian kekhasan, kehormatan, dan terkadang kekaguman dari negara-negara lain yang dapat berupa kekuatan dan keahlian militer, pemimpin dalam sains dan teknologi, tanda-tanda nyata industrialisasi bagi negara-negara berkembang, bahkan dalam hal olahraga. Dalam konteks Korea Selatan, tujuan ini nampak pada Visi Global Korea itu sendiri, yakni mematangkan posisinya untuk menjadi negara yang lebih terhormat dan mendapatkan tempatnya diantara negara-negara maju dengan secara aktif dan mampu menawarkan solusi untk menyelesaikan isu-isu yang di hadapi komunitas internasional.

Dalam memformulasikan kebijakan dan strategi untuk mencapai tujuan tertentu, suatu negara akan secara eksplisit maupun implisit mempertanyakan empat pertanyaan, yakni (Holsti, 1995: 119):1. Dengan tujuan tersebut, apa yang kita ingin negara $\mathrm{B}$ lakukan atau tidak lakukan? Atau (x); 2. Bagaimana kita membuat negara B melakukan atau tidak melakukan (x)?; 3.Kapabilitas apa yang yang kita miliki yang dapat digunakan untuk membujuk negara $\mathrm{B}$ mengikuti keinginan kita?; 4. Apa kemungkinan respon yang diberikan negara $B$ terhadap upaya kita untuk mempengaruhi perilakunya?

\section{HASIL DAN PEMBAHASAN}

Dalam artikel ini, penulis akan melihat bagaimana aksi kebijakan luar negeri Korea Selatan dengan menggunakan tiga dari empat pertanyaan diatas, yakni:

1. Perilaku apa yang diinginkan oleh Korea Selatan dari Korea Utara? Yakni Korea Utara tidak melakukan aksi provokasi yang dapat mengganggu stabilitas perdamaian di Semenanjung Korea, baik itu kebijakankebijakan garis kerasnya, program nuklir ataupun provokasi militer. Dalam kerangka Holsti, perilaku demikiran dikenal dengan negative power atau deterrence, yakni ketika negara A bertindak dalam kerangka untuk mencegah aksi-aksi tertentu yang tidak diinginkan atau tidak sejalan dengan kepentingannya dari negara B (Holsti, 1995: 120).

2. Bagaimana upaya Korea Selatan untuk membuat Korea Utara untuk tidak melakukan aksi provokatif? Menurut Holsti, terdapat enam taktik yang pada umumnya digunakan oleh negara-negara dalam melancarkan pengaruhnya untuk mengubah perilaku dari negara lain, yakni: (1) persuasi, ketika suatu negara secara sederhana menginisiasikan atau mendiskusikan sebuah proposal dengan negara lain dan menimbulkan respon yang diinginkan. Dalam situasi ini biasanya suatu negara mempresentasikan kondisi, menegaskan tujuan-tujuan mereka dan melakukan persuasi dengan mempresentasikan data untuk mengilustrasikan kebenaran pandangan atau tingkat kebutuhan mereka. Sewaktu-waktu dapat menggunakan ancaman atau penawaran hadiah untuk membujuk negara lain. (2) Penawaran Hadiah, yakni situasi dimana suatu negara A berjanji melakukan sesuatu yang baik, atau menawarkan sejumlah keuntungan, jika negara $\mathrm{B}$ mengabulkan keinginannya. (3) Pemberian Hadiah, yakni kondisi dimana suatu negara A memberikan hadiah terhadap negara $\mathrm{B}$ dengan harapan negara B kemudian mengikuti keinginan dari negara A. (4) Ancaman Hukuman, dapat berupa ancaman frase diplomatik atau verbal untuk menegaskan bahwa negara $\mathrm{B}$ akan bertanggungjawab atas perilakunya atau ancaman penaikan tariff, boikot, embargo atau deprivasi atau pencabutan sejumlah keuntungan yang telah diberikan sebelumnya. (5) Penalti Hukuman NonKekerasan, yakni situasi dimana ancaman benar-benar dilaksanakan dengan harapan dapat mengubah perilaku dari negara $\mathrm{B}$, yang pada banyak kasus, tidak dapat diubah dengan alat lain. (6) Kekerasan, yang pada umumnya digunakan pada era dimana pilihan instrumen kebijakan masih sangat terbatas pada kekuatan militer untuk tawar menawar.

3. Kapabilitas apa yang dimiliki Korea Selatan yang digunakan untuk membujuk Korea Utara? Menurut Robert Dahl, kapabilitas dapat dibagi dua, yakni yang tangible seperti uang, kesejahteraan, informasi, aliansi politik, posisi resmi dan sebagainya, dan yang intangible seperti personalitas dan kualitas kepemimpinan. Namun yang paling penting berkenaan dengan kapabilitas untuk mempengaruhi adalah mobilisasi kapabilitas 
tersebut untuk tujuan-tujuan politik atau dalam hal ini untuk mendukung tujuan kebijakan luar negeri (Holsti, 1995: 121).
Untuk mempermudah proses analisis, penulis mengolahnya menjadi tabel dibawah ini:

Tabel 1. Taktik Pengaruh dan Sumber Daya dalam Mencegah Aksi Provokasi Korea Utara

\begin{tabular}{|c|c|c|c|}
\hline Tahun & Aksi Provokasi & Taktik Pengaruh yang digunakan & Sumber daya yang digunakan \\
\hline 2008 & $\begin{array}{l}\text { Korea Utara meminta } \\
\text { pengimplementasian the June 15, } \\
2000 \text { Joint Declaration dan the } \\
\text { October 4, 2007 Declaration sebagai } \\
\text { tambahan terhadap penghentian } \\
\text { proposal Lee Myung Bak Vision } \\
3000 \text { thru Denuclearizaton. } \\
\text { Mengusir personel Korea Selatan } \\
\text { dari kantor Konsultasi Pertukaran dan } \\
\text { Kerjasama Inter-Korea di Kaesong } \\
\text { (27 Maret 2008) } \\
\text { Memutuskan semua kontak dan Inter- } \\
\text { Korea Talks secara sepihak (29 Maret } \\
\text { 2008) } \\
\text { Mulai mengkritisi secara personal } \\
\text { presiden Lee Myung Bak (1 April 2008). } \\
\text { Penembakkan turis Korea Selatan di } \\
\text { fasilitas wisata gunung Keumgang } \\
\text { (11 juli 2008) } \\
\text { Mendeklarasikan akan pemberlakuan } \\
\text { pelarangan perlintasan MDL melalui } \\
\text { darat tertanggal } 1 \text { desember } 2008 \\
\text { dan secara unilateral menutup } \\
\text { kantor liaison di Panmunjom dan } \\
\text { memutuskan inter-Korean hotline } \\
\text { (12 Nopember 2008) }\end{array}$ & $\begin{array}{l}\text { Persuasi: } \\
\text { Pernyataan Presiden: Dalam } \\
\text { wawancara dengan Washington Post } \\
\text { (April 2008); Pada pidato upacara Hari } \\
\text { Peringatan (6 juni 2008); Dalam pidato } \\
\text { pembuka di Dewan Nasional (11 juli } \\
\text { 2008); Dalam pidato hari Kemerdekaan } \\
\text { dan perayaan } 60 \text { tahun Korea Selatan } \\
\text { (15 agustus 2008); Pada pidato } \\
\text { pembukaan dalam National Unification } \\
\text { Advisory Council (23 september } \\
\text { 2008) Presiden Lee Myung Bak selalu } \\
\text { menekankan bahwa demi keuntungan } \\
\text { bersama dan kesejahteraan kedua } \\
\text { Korea, Korea Utara harus berpartisipasi } \\
\text { dalam Dialog langsung dan terbuka } \\
\text { dengan Korea Selatan. } \\
\text { Dialog-Inter Korea: } 37^{\text {th }} \text { Inter- } \\
\text { Korean Military Working-level } \\
\text { Talks (2 Oktober 2008) } \\
\text { Penawaran Hadiah: Vision } 3000 \\
\text { through Denuclearization and } \\
\text { Openess } \\
\text { Pemberian Hadiah: Bantuan } \\
\text { kemanusiaan ke Utara sebanyak } \\
\text { US\$4.08 juta melalui UNICEF }\end{array}$ & $\begin{array}{l}\text { Ekonomi: } \\
\text { Keberhasilan Korea Selatan } \\
\text { mencapai pembangunan dan } \\
\text { bahkan diakui sebagai negara } \\
\text { maju pada tahun 2010, Korea } \\
\text { Selatan semakin percaya } \\
\text { diri dalam menggunakan } \\
\text { kapabilitasnya dibidang } \\
\text { ekonomi untuk membujuk } \\
\text { Korea Utara untuk denuklirisasi } \\
\text { dan terbuka terhadap dunia luar. }\end{array}$ \\
\hline 2009 & $\begin{array}{l}\text { Mengumumkan 'all-out } \\
\text { confrontational posture' (17 } \\
\text { januari 2009) Mendeklarasikan } \\
\text { bahwa Korea Utara tidak akan lagi } \\
\text { "bekerja sama untuk resolusi tensi } \\
\text { militer dan politik" dan "mencabut } \\
\text { ketetapan Northern Limit Line di } \\
\text { Laut Kuning" (30 januari 2009) } \\
\text { Secara sepihak memperburuk } \\
\text { inter-Korean military hotline dan } \\
\text { menahan lalu lintas perbatasan. } \\
\text { Menawan pekerja Korea Selatan } \\
\text { di Komplek Industri Kaesong ( } 30 \\
\text { maret 2009) } \\
\text { Meluncurkan roket jarak panjang } \\
\text { (5 april 2009) } \\
\text { Uji coba nuklir kedua (25 Mei } \\
\text { 2009). } \\
\text { Mendeklarasikan akan memboikot } \\
\text { Six-Party Talks (14 April 2009) } \\
\text { Mendeklarasikan maksud untuk } \\
\text { membangun reaktor light-water } \\
\text { dan mengembangkan teknologi } \\
\text { untu menghasilkan bahan bakar } \\
\text { reaktor nuklir (29 April 2009) } \\
\text { Menyatakan bahwa Pyongyang } \\
\text { tidak akan menyerah akan senjata } \\
\text { nuklir dan akan mempersenjatai } \\
\text { semua plutoniumnya dan melakuka } \\
\text { pengayaan uranium (13 Juni 2009). }\end{array}$ & $\begin{array}{l}\text { Persuasi: } \\
\text { Pernyataan Presiden: Dalam State } \\
\text { Union Speech } 2 \text { januari 2009; Radio } \\
\text { Speech ke-8 (9 febuari 2009); Dalam } \\
\text { pidato perayaan Hari Pergerakan } \\
\text { Kemerdekaan ke-80 (1 Maret 2009); } \\
\text { Wawancara pers asing G20 Summit } \\
\text { (3 April 2009); Korea-China Summit } \\
\text { di G20 Summit (3 April 2009); Radio } \\
\text { Speech ke-16 (1 Juni 2009); Pidato } \\
\text { Upacara Hari Peringatan ke-53 (6 } \\
\text { Juni 2009); Pidato Upacara inagurasi } \\
\text { the National Advisory Council ke- } \\
\text { 14 (1 Juli 2009); Pidato Upacara } \\
\text { Hari Kebebasan Nasional ke 64 (15 } \\
\text { Agustus 2009); ROK-US Summit } \\
\text { Joint Press Conference (19 Nopember } \\
\text { 2009), dalam beberapa kesempatan } \\
\text { tersebut Presiden Lee Myung Bak } \\
\text { selalui mengajukan Dialog Inter- } \\
\text { Korea kapan pun dan pada tingkat } \\
\text { apapun, bahwa Korea Selatan selalu } \\
\text { terbuka dan meminta Korea Utara } \\
\text { untuk kembali ke Six Party Talks. } \\
\text { Dialog Inter-Korea: Inter-Korean } \\
\text { Working-level Talks in GIC putara } 1 \text { (11 } \\
\text { Juni 2009); putaran } 2 \text { (19 Juni 2009); } \\
\text { putara 3(2 Juli 2007). } \\
\text { Kunjungan Duka Cita Delegasi } \\
\text { Kore Utara ke Seoul (21-23 } \\
\text { Agustus 2009) }\end{array}$ & $\begin{array}{l}\text { Ekonomi } \\
\text { Aliansi: hal utama yang } \\
\text { menjadikan sulitnya bagi } \\
\text { Korea Utara dan Korea Selatan } \\
\text { untuk hidup berdampingan } \\
\text { secara damai adalah karena } \\
\text { ambisi nuklir Korea Utara yang } \\
\text { nampak tidak padam bahkan } \\
\text { setelah } 10 \text { tahun di manjakan } \\
\text { dengan Sunshine policy Korea } \\
\text { Selatan. Namun disisi lain, hal } \\
\text { yang juga menyebabkan Korea } \\
\text { Utara enggan untuk melepaskan } \\
\text { nuklirnya adalah karena adanya } \\
\text { pasukan Amerika Serikat di } \\
\text { Korea Selatan. Oleh karena itu, } \\
\text { Korea Selatan -dalam the Grand } \\
\text { Bargain- menjajikan akan } \\
\text { menjamin jaminan keamanan } \\
\text { yang konkrit bagi Korea Utara, } \\
\text { termasuk nampaknya tentang } \\
\text { kekhawatiran mereka akan } \\
\text { Amerika Serikat. } \\
\text { Jaringan Diplomasi: Korea } \\
\text { Selatan memafaatkkan } \\
\text { jaringan diplomasinya untuk } \\
\text { mendapatkan dukungan dunia } \\
\text { internasional terhadap sanksi } \\
\text { atau kemungkinan tindakan } \\
\text { balasan terhadap aksi provokasi } \\
\text { Korea Utara. }\end{array}$ \\
\hline
\end{tabular}


2010 Menenggelamkan Kapal Perang Angakatan Laut Korea Selatan Cheonan (26 Maret 2010), dan Penyerangan artileri ke pulau Yeonpyeong (23 Nopember 2010)
Inter-Korean Red Cross Meetings and Working-level Talks pertama (26 Agustus 2009); kedua (16 Oktober 2009)

Penawaran Hadiah: Vision 3000 thru Denuclearization and Openess The New Peace Initiative for the Korean Peninsula (15 Agustus 2009) The Grand Bargain (21 September 2009)

Pemberian Hadiah: Bantuan kemanusiaan: mengirimkan 400.000 dosis Tamiflu dan 100.000 dosis Relenza untuk mengatasi flu babi di Korea Utara (18 Desember 2009) Ancaman Hukuman: Dalam pernyataan pemerintah tanggal 5 April 2009, menyatakan bahwa peluncuran misil Korea Utara tersebut merupakan pelanggaran terhadap Resolusi DK PBB 1718 dan merupakan tindakan provokatif yang mengancamn stabilitas dan perdamaian di Senanjung Korea dan Asia Timur. Bahwa Korea Selatan akan memperkuat persiapannya terhadap kemungkinan aksi provokatif lebih lanjut dari Korea Utara. Pernyataan pemerintah pada25 Mei 2009 yangmenyatakan bahwa uji coba nuklir Korea Utara mengancam stabilitas tidak hanya di Semenanjung Korea tetapi juga Asia Timur dan lainnya. Bahwa aksi provokatif ini tidak dapat diterima dan Korea Selatan akan bekerja dengan dekat bersama negara partisipan Six Party Talks dan komunitas internasional untuk memastikan DK PBB mengambil tindakan yang layak.

Persuasi:

Pernyataan Presiden: Pidato Tahun Baru (4 Januari 2010); Pidato Hari Pergerakan Kemerdekaan ke-91 (1Maret 2010); Pidato Hari Peringatan ke-55 (6 Juni 2010); Pidato Hari Kemerdekaan Nasional (15 Agutus 2010)

Dialog Inter-Korea: $38^{\text {th }}$ InterKorean Military Working-level Talks (30 September 2010) Inter-Korean Working-level Talks on GIC putaran keempat (1 Februari 2010) Inter-Korean Red Cross Meetings and Working-level Talks ketiga (17, 24 agustus dan 1 oktober 2010); keempat (24-26 Oktober 2010).

\section{Pemberian Hadiah:}

Korea Selatan mengirimkan 200.000 liter hand sanitizer pada 3 februari 2010 melalui Palang Merah Nasionalnya. Walau ditengah semakin memburuknya hubungan inter-Korea, Korea Selatan
Ekonomi: Korea Selatan pada akhirnya memobilisasi kapabilitas ekonominya, termasuk kontrol terhadap proyek-proyek kerjasama dan pertukaran inter-Korea untuk menghukum Korea Utara.

Aliansi \& Militer: Korea

Selatan melakukan sejumlah latihan militer bersama dengan aliansinya dengan tujuan untuk menunjukkan dan meningkatkan kesiapan pertahanan Korea Selatan terhadap kemungkinan aksi provokasi Korea Utara di masa depan. 


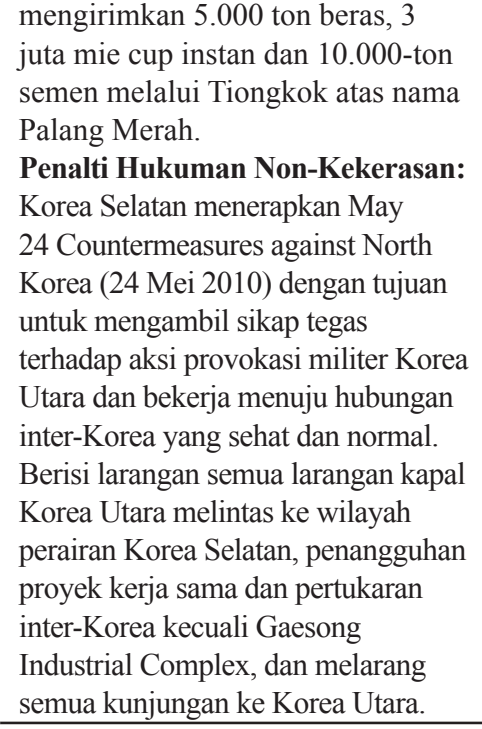

Sumber: Diolah oleh Penulis Dari Berbagai Sumber

Berdasarkan tabel diatas dapat dilihat bahwa sepanjang tahun 2008, sejak awal pemerintahan Lee Myung Bak, Korea Utara telah melakukan sejumlah kebijakan garis keras terhadap Korea Selatan. Aksi provokasi dari Korea Utara itu sendiri bagi Korea Selatan bukanlah merupakan isu baru, melainkan sudah berlangsung sejak berhentinya perang Korea dengan perjanjian gencatan senjata -bukan kesepakatan damai- pada tahun 1953. Oleh karena itu, secara hukum Korea Selatan dan Korea Utara hingga hari ini masih dalam kondisi perang, sehingga aksi-aksi provokasi bahkan agresi kerap terjadi diantara kedua negara.

Dalam upaya untuk meningkatkan kualitas hubungan inter-Korea, Presiden Korea Selatan, Lee Myung Bak pun telah merancang sejumlah tujuan dan rencana kerja dalam kebijakannya terhadap Korea Utara, termasuk rencana aksi yang dinilai favourable bagi Korea Utara sehingga dapat mencegah kemungkinan adanya aksi-aksi provokatif atau perilaku yang tidak diinginkan dari Korea Utara. Korea Selatan memperkenalkan Visi 3000 atau Vision 3000 thru Denuclearization and Openess yang merupakan kebijakan operasional dari kebijakan 'Utara' Korea Selatan, Mutual Benefits and Common Prosperity Policy.

Ide dari Visi 3000 tersebut utamanya ditujukan untuk mengatasi isu nuklir Korea Utara yang selama ini merupakan batu penghalang paling besar bagi kemajuan dan perkembangan hubungan inter-Korea, yakni dengan menawarkan peningkatan bantuan aktif untuk membantu meningkatkan pendapatan per kapitanya hingga 3.000 US dollar dalam sepuluh tahun, jika halnya Korea Utara meninggalkan senjata nuklirnya. Kebijakan tersebut mengimplikasikan bahwa selama disana terdapat perkembangan dalam proses denuklirisasi oleh Korea Utara, maka Korea Selatan akan menyediakan paket dukungan yang menawarkan rekonstruksi ekonomi dan peningkatan hidup warganya termasuk pendidikan, modal, infrastruktur dan kesejahteraan. Bersamaan dengan itu, Korea Selatan juga menerapkan pendekatan yang fleksibel dalam hubungan inter-Korea dan terus mengupayakan progres yang harmonis antara kerjasama inter-Korea dan internasional.

Akan tetapi, di dalam sistem politik dimana setiap internasional dimana tidak adanya kekuasaan yang dapat mengatur perilaku dari negara -berdaulat- setiap negara pun bergerak sesuai dengan kepentingannya masing-masing dan terkadang bertentangan dengan tujuan dan kepentingan dari negara lain. Berdasarkan tabulasi diatas, peneliti mengidentifikasi taktik pengaruh yang digunakan oleh Korea Selatan berdasarkan aksi provokasi yang dilakukan per tahunnya, sebagai berikut:

1. Padatahun2008, responKoreaUtaraterhadap kebijakan baru Korea Selatan tidaklah positif. Korea Utara menerapkan sejumlah kebijakan garis keras dan aksi provokatif seperti menuntut implementasi tak bersyarat terhadap perjanjian-perjanjian inter-Korea (the June 152000 Joint Declaration dan the October 42007 Declaration) sebagai 
tambahan terhadap pembatalan Visi 3000 Lee Myung Bak. Korea Utara menahan pegawai Korea Selatan di Kompleks Industri Kaesong (27 Maret 2008), mencabut seluruh pertemuan inter-Korea secara sepihak (29 maret 2008), dan sejak 1 April 2008, Korea Utara mulai mengkritisi dan menghina presiden Lee Myung Bak. Hubungan interKorea pun mengalami penurunan sejak terjadinya insiden penembakkan turis Korea Selatan di area wisata gunung Keumgang (1 April 2008). Menuju akhir tahun 2008, pada tanggal 12 Nopember 2008, Korea Utara mendeklarasikan akan pemberlakuan pelarangan perlintasan MDL (Military Demarcation Line) melalui darat tertanggal 1 desember 2008 dan secara unilateral menutup kantor liaison di Panmunjom dan memutuskan inter-Korean hotline. Taktik pengaruh yang digunakan untuk mencegah kemungkinan adanya aksi provokasi lebih lanjut dari Korea Utara dan semakin memburuknya hubungan inter-Korea Korea Selatan mengadopsi sikap 'penyelesaian masalah melalui dialog' dan terus mengupayakan perbicangan tulus dengan Korea Utara. Dalam beberapa kesempatan pidato dan wawancara, seperti wawacara dengan Washington Post (17 April 2008), pidato upacara Hari Peringatan (6 juni 2008), dalam pidatopembuka di Dewan Nasional(11 juli 2008), hari Kemerdekaan dan perayaan 60 tahun Korea Selatan (15 agustus 2008) dan pada pidato pembukaan dalam National Unification Advisory Council (23 September 2008), Presiden Lee Myung Bak terus menegaskan posisinya dan kebijakan 'Korea Utara' Korea Selatan (Mutual Benefits and Common Prosperity Policy dan kebijakan operasionalnya yakni Visi 3000) merupakan kebijakan yang tulus dan menguntungkan kedua pihak serta ajakan untuk berdialog dan berdiskusi untuk mengklarifikasi kebijakan baru Korea Selatan dan pemahaman posisi satu sama lain. Persuasi juga dilakukan oleh Korea Selatan melalui Dialog inter-Korea, dimana pada tahun 2008 terdapat satu Dialog di sektor militer atas usulan dari Korea Utara, yakni $37^{\text {th }}$ Inter-Korean Military Working-level Talks yang dilaksanakan pada tanggal 2 Oktober 2008. Selain persuasi dan penawaran hadiah tersebut, Korea Selatan juga menerapkan taktik pemberian hadiah dengan mengirimkan bantuan kemanusiaan ke Korea Utara sebanyak 4.08 juta US Dollar melalui UNICEF sebagai bentuk komitmennya terhadap isu kemanusiaan dan aktor global. Sebagaimana dapat dilihat, sumber daya yang dimobilisasi oleh Korea Selatan untuk mendukung dan melancarkan tujuan kebijakan luar negerinya adalah sumber daya ekonomi. Keberhasilan Korea Selatan mencapai pembangunan dan bahkan berhasil masuk ke dalam golongan negaranegara maju, Korea Selatan semakin percaya diri dalam menggunakan kapabilitasnya dibidang ekonomi untuk membujuk Korea Utara untuk denuklirisasi dan terbuka terhadap dunia luar. Tahun 2008, nampaknya merupakan periode dimana pemerintahan Lee Myung Bak bekerja untuk membangun hubungan inter-Korea yang baru dan memanage keberlangsungan stabilitas dalam hubungan inter-Korea dan Semenanjung dengan menahan atau membatasi diri ketika berhadap dengan kritikan dan kebijakan garis keras Korea Utara.

2. Tahun 2009 , merupakan tahun dimana aksi provokasi Korea Utara meningkat pada level yang lebih tinggi dibandingkan tahun sebelumnya. Korea Utara mengumumkan "all-out confrontational posture" (17 januari 2009); mendeklarasikan bahwa Korea Utara tidak akan lagi "bekerjasama untuk resolusi tensi militer dan politik" dan "mencabut ketetapan Northern Limit Line (NLL) di Laut Kuning (30 Januari 2009); meluncurkan roket jarak jauh (5 April 2009); mendeklarasikan akan memboikot Six Party Talks (14 April 2009); mendeklarasikan maksud untuk membangun light-water reactor dan mengembangkan teknologi untuk menghasilkan bahan bakar nuklir; melakukan uji coba nuklir kedua (25 Mei 2009), dan; menyatakan bahwa Pyongyang tidak akan menyerahkan ambisi nuklirnya dan akan mempersenjatai semua plutoniumnya dan melakukan pengayaan uranium(13 juni 2009). Perilaku yang paling tidak diinginkan atau tidak sejalan dengan tujuan kebijakan luar negeri dan keamanan KoreaSelatan, yaitunuklir, kembaliberulang tahun ini. Tidak jauh dengan periode tahun sebelumnya, taktik persuasi pun tetap digunakan oleh Korea Selatan dalam mencegah kemungkinan aksi provokasi 
lebih lanjut dari Korea Utara, yang dapat meningkatkan tensi konflik di Semenanjung Korea. Pada beberapa kesempatan seperti pidato dalam State Union Speech (2 januari 2009); Radio Speech ke-8 (9 febuari 2009); Dalam pidato perayaan Hari Pergerakan Kemerdekaan ke-80 (1 Maret 2009); Wawancara pers asing G20 Summit (3 April 2009); Korea-China Summit di G20 Summit (3 April 2009); Radio Speech ke-16 (1 Juni 2009); Pidato Upacara Hari Peringatan ke-53 (6 Juni 2009); Pidato Upacara inagurasi the National Advisory Council ke-14 (1 Juli 2009); Pidato Upacara Hari Kebebasan Nasional ke 64 (15 Agustus 2009); ROK-US Summit Joint Press Conference (19 Nopember 2009), Presiden Lee Myung Bak selalu menekankan pentingnya dialog inter-Korea dan menyatakan bahwa Korea Selatan selalu terbuka untuk Dialog Inter-Korea kapan pun, pada tingkat apapun dan dimana pun, bahwa Korea Selatan selalu terbuka dan meminta Korea Utara untuk kembali ke Six Party Talks. Dialog inter-Korea pun terus dilakukan untuk membicarakan isu-isu tertunda dan program kerjasama dan pertukaran inter-Korea, diantaranya Inter-Korean Working-level Talks in GIC putaran 1 (11 Juni 2009); putaran 2 (19 Juni 2009); putara 3(2 Juli 2007). Kunjungan Duka Cita Delegasi Korea Utara ke Seoul (21-23 Agustus 2009), dan; Inter-Korean Red Cross Meetings and Working-level Talks pertama (26 Agustus 2009); kedua (16 Oktober 2009). Selain itu, didasarkan pada Visi 3000, Korea Selatan pun kembali menawaran sejumlah keuntungan yang ditujukan untuk membujuk Korea Utara agar melepaskan ambisi nuklirnya. Pada 15 agustus, pada pidato kemerdekaan Korea Selatan, presiden Lee Myung Bak menginisiasikan the New Peace Initiative for the Korean Peninsula yang menyatakan bahwa jika Korea Utara meninggalkan program nuklirnya, demi menciptakan kepercayaan bersama dalam hubungan inter-Korea, Korea Selatan akan membantu pengimplementasian program kerjasama global untuk meningkatkan kualitas hidup Korea Utara, menginisiasikan pertemuan tingkat tinggi inter-Korea yang didedikasikan untuk melahirkan komunitas ekonomi bersama untuk mengeksekusi proyek pembangunan ekonomi, pendidikan, modal, infrastruktur dan kualitas hidup. Pada saat yang bersamaan, perbincangan mengenaipengurangan senjatakonvensional juga penting untuk meningkatkan trustbuilding dalan hubungan inter-Korea. Sejalan dengan penawaran tersebut, Lee Myung Bak mengajukan the Grand Bargain (21 September 2009), sebuah kesepkatan komprehensif yang mengusulkan untuk menyediakan Korea Utara jaminan keamanan yang konkret dan untuk mencari dukungan internasional skala besar bersamaan dengan Korea Utara meninggalkan komponen utama dari program nuklirnya melalui Six Party Talks. Namun aksi provokasi nuklir Korea Utara juga tentunya tidak keluar dari kecaman Korea Selatan, dalam pernyataan pemerintah tanggal 5 April 2009, Korea Selatan menyatakan bahwa peluncuran misil Korea Utara tersebut merupakan pelanggaran terhadap Resolusi DK PBB 1718 dan merupakan tindakan provokatif yang mengancamn stabilitas dan perdamaian di Senanjung Korea dan Asia Timur. Dan bahwa Korea Selatan akan memperkuat persiapannya terhadap kemungkinan aksi provokatif lebih lanjut dari Korea Utara. Kemudian pada pernyataan pemerintah pada 25 Mei 2009 yang menyatakan bahwa uji coba nuklir Korea Utara mengancam stabilitas tidak hanya di Semenanjung Korea tetapi juga Asia Timur dan lainnya. Bahwa aksi provokatif ini tidak dapat diterima dan Korea Selatan akan bekerja dengan dekat bersama negara partisipan Six Party Talks dan komunitas internasional untuk memastikan DK PBB mengambil tindakan yang layak. Dua pernyataan tersebut menunjukkan bahwa perilaku dari Korea Utara tersebut mengancam Korea Selatan dan bahwa akan ada konsekuensi dari tindakan tersebut(taktikancamanhukuman). Akan tetapi, jika pun Korea Selatan mulai menunjjukan sikap keras terhadap aksi provokasi Korea Utara, Korea Selatan tetap mempertahankan proses dialog dan pengiriman bantuan kemanusiaan ke Korea Utara -mengirimkan 400.000 dosis Tamiflu dn 100.000 dosis Relenza untuk mengatasi flu babi di Korea Utara (18 Desember 2008)- 
sebagai bentuk komitmenya terhadap cita-cita Mutual Benefits dan Common Prosperity Policy dan untuk menciptakan situasi yang tetap mendukung Dialog interKorea. Sebagaimana dapat dilihat bahwa Korea Selatan memobilisasi, terutama kapabilitas ekonominya, untuk membujuk Korea Utara untuk tidak melakukan aksi provokasi lebih lanjut -terutama provokasi nuklir. Aliansi dan jaringan diplomasi Korea Selatan merupakan sumber daya yang juga digunakan untuk mendukung pencapaian dan untuk mempertahankan tujuan-tujuan kebijakan luar negerinya. Hal tersebut karena hal utama yang menjadikan sulitnya bagi Korea Utara dan Korea Selatan untuk hidup berdampingan secara damai adalah karena ambisi nuklir Korea Utara yang nampak tidak padam, bahkan setelah 10 tahun di manjakan dengan Sunshine policy Korea Selatan. Oleh karena itu, Korea Selatan tetap mempertahankan aliansinya dengan Amerika Serikat untuk mendapatkan jaminan keamanan dari ancaman nuklir tersebut. Namun disisi lain, hal yang juga menyebabkan Korea Utara enggan untuk melepaskan nuklirnya. Oleh karena itu, Korea Selatan -dalam the Grand Bargain- menjanjikan akan menjamin jaminan keamanan yang konkrit bagi Korea Utara, termasuk tentang kekhawatiran mereka akan Amerika Serikat. Selain itu, Korea Selatan memanfaatkan jaringan diplomasinya untuk mendapatkan dukungan dunia internasional terhadap sanksi atau kemungkinan tindakan balasan terhadap aksi provokasi Korea Utara.

3. Tahun 2010, merupakan tahun dimana eskalasi konflik di semenanjung meningkat pada level yang lebih tinggi lagi dari periode sebelumnya. Hal tersebut karena Korea Utara kembali melakukan aksi provokasi, yang dalam hal ini adalah provokasi militer yang ditujukan langsung pada perangkat militer dan pertahanan Korea Selatan, yakni insiden tenggelamnya kapal Cheonan yang terjadi pada tanggal 26 Maret 2010 yang menewaskan 46 anak kapal di dalamnya. Tidak berhenti disitu saja, Korea utara kembali melakukan aksi yang provokatif dengan melancarkan penembakkan artileri ke Pulau Yeonpyeong yang tidak hanya mengorbankan tentara Korea Selatan tetapi juga penduduk sipil dan bangunan bangunan di pulau tersebut. Menghadapi aksi provokatif Korea Utara yang tidak dapat dihentikan, Korea Selatan akhirnya menggunakan taktik penalti hukuman nonkekerasan, yakni dengan dikeluarnnya the may 24 Countermeasures against North Korea. Presiden Lee Myung Bak, dalam pidatonya ke publik, menyatakan bahwa Korea Selatan telah selalu mentoleransi brutalitas Korea Utara karena Korea Selatan selalu merindukan perdamaian di Semenanjung Korea. Akan tetapi situasi saat ini telah berbeda. Oleh karena itu Korea Selatan tidak akan mentolelir lagi aksi provokasi dari Korea Utara dan mempertahankan sikap proactive deterrence. Yakni jika wilayah darat, air dan udaranya dilanggar, Korea Selatan akan melaksanakan haknya untuk mempertahankan diri dan meminta Korea Utara untuk meminta maaf dan menghukum pihak yang bertanggungjawab. Lee Myung Bak juga menyatakan bahwa tujuan Korea Selatan bukanlah konfrontasi militer, melainkan selalu untuk mencapai stabilitas dan perdamaian yang nyata di Semenanjung Korea, kesejahteraan bagi seluruh Korea (Utara dan Selatan) dan reunifikasi damai. Berkaitan dengan tindakan balasan ini, kementerian unfikasi, kementerian luar negeri dan perdagangan, serta kementerian pertahanan Korea Selatan masing-masing menjalankan tindakan balasan. Kementerian Unifikasi mengambil lima tindakan balasan, yakni: pertama, kapal Korea Utara dilarang memasuki wilayah perairan Korea Selatan, termasuk melalui selat jeju. Kedua, Semua perdangan diantara kedua Korea akan ditahan, termasuk pengiriman barang dan material. Ketiga, Warga Korea Selatan dilarang untuk mengunjungi Korea Utara, termasuk kontak dengan orang Korea Utara. Keempat, investasi dan pembangunan distrik ekonomi bersama baru dengan Korea Utara akan dilarang, kecuali program yang sudah berlangsung di Kompleks Industri Kaesong. Kelima, berdasarkan prinsip, program bantuan akan dihentikan, kecuali yang bersifat murni kemanusiaan. Menteri Luar Negeri dan Perdagangan memutuskan untuk mempromosikan 'rasa penghukuman' dalam komunitasinternasionaldanuntukmengajukan kasus Cheonan ke Dewan Keamanan PBB. 
Disisi lain, Menteri Pertahanan Nasional Korea Selatan mengumumkan bahwa mereka akan memberlakukan pelarangan berlayar ke wilayah peraiaran Korea Selatan bagi Korea Utara, mengembalikan propaganda broadcasts yang telah dihentikan sejak tahun 2004, melakukan latihan kapal selam dengan Amerika Serikat (ROK-US anti-submarine drills) di Laut Kuning dan memperkuat aktifitas PSI, termasuk latihan pencegatan maritime (maritime interdiction exercise. Sebelumnya, Korea Selatan pun melakukan taktik persuasi dengan melaksanakan dialog inter-Korea, $38^{\text {th }}$ Inter-Korean Military Working-level Talks (30 September 2010) dan Inter-Korean Working-level Talks on GIC putaran keempat (1 Februari 2010). Namun upaya tersebut nampaknya tidak mampu mencegah aksi provokasi Korea Utara. Setelah insiden Cheonan dan Yeonpyeong, dialog inter-Korea pun hanya difokuskan pada bidang kemanusiaan yakni dengan dilaksanakannya Inter-Korean Red Cross Meetings and Working-level Talks ketiga (17, 24 agustus dan 1 oktober 2010); keempat (24-26 Oktober 2010) yang konsen utamanya adalah pelaksanakan reuni keluarga terpisah. Selain itu, Korea Selatan mengirimkan 200.000-liter hand sanitizer pada 3 februari 2010 melalui Palang Merah Nasionalnya. Walau ditengah semakin memburuknya hubungan interKorea, Korea Selatan mengirimkan 5.000 ton beras, 3 juta mie cup instan dan 10.000-ton semen melalui Tiongkok atas nama Palang Merah pada tanggal 4 september 2010. Korea Selatan pada akhirnya memobilisasi kapabilitas ekonominya, termasuk kontrol terhadap proyek-proyek kerjasama dan pertukaran inter-Korea untuk menghukum Korea Utara. Selain itu, Korea Selatan juga melakukan sejumlah latihan militer bersama dengan aliansinya dengan tujuan untuk menunjukkan dan meningkatkan kesiapan pertahanan Korea Selatan terhadap kemungkinan aksi provokasi Korea Utara di masa depan dan juga jaringan diplomasinya untuk mendapatkan dukungan dari dunia internasional dengan mempromosikan 'rasa penghukuman' sebagaimana disebutkan dalam tindakan balasan kementerian luar negeri dan perdagangan Korea Selatan.
Berkenaan dengan penggunaan taktik pengaruh yang digunakan oleh Korea Selatan dalam mencegah aksi provokasi dari Korea Utara, menurut Professor Kim Ee-Soek dari Kangwon Institute of Unification Studies, tergantung pada kasus dan nature dari tindakan agresif Korea Utara, yakni jenis dan tingkat ancaman yang dilakukan.

Dalam banyak kasus, Korea Selatan tidak dapat berbuat banyak karena, sebagaimana beliau nyatakan, pasukan Amerika yang ditempatkan di Korea mencoba untuk mencegah eskalasi krisis. Dalam situasi tersebut biasanya mereka akan membujuk Korea Selatan untuk tidak melakukan tindakan agresif. Oleh karena itu, Korea Selatan pun tidak dapat berbuat banyak atau mengambil aksi yang dapat secara efektif menghentikan aksi provokasi Korea Utara, melainkan menggunakan jalan atau alat lain yang tersedia seperti statement -seperti dipaparkan diatas-, propaganda dan dengan mendemonstrasikan sejumlah kekuatan militer.

Hal tersebut merupakan ketidakleluasaan utama yang dihadapi oleh pemerintah Korea Selatan. Taktik yang digunakan, oleh karenanya, lebih pada persuasi dan alat diplomasi. Jikapun Korea Selatan melakukan tindakan balasan yang keras, hal tersebut lebih ditujukan justru untuk publik Korea Selatan itu sendiri. Yakni untuk memperlihatkan bahwa pemerintah telah bereaksi kuat terhadap provokasi Korea Utara, karena mayoritas dari mereka menginginkan reaksi keras pemerintah terhadap ancaman Korea Utara. Akan tetapi hal tersebut bukanlah alat yang utama, melainkan sewaktu-waktu dengan mendemnstrasikan intensi perang dan pada akhirnya selalu bergantung pada alat diplomatik.

Mengapa demikian? Professor Kim Eui Kon dari Inha University menyebutkan bahwa tujuan utama kebijakan Korea Selatan vis-a vis Korea Utara adalah untuk mencapai unifikasi dan hidup berdampingan secara damai, yakni untuk mencapai perdamaian dankesejahteraan bangsa Korea. Penggunaan opsi lain, seperti perang, tidaklah terpikirkan oleh Seoul karena perang dikhawatirkan akan membawa ekonomi Korea Selatan ke masa tiga puluh tahun sebelumnya, begitupula dengan kebijakan luar negeri Korea Selatan yang meliputi tujuan ekonomi, politik dan sosial di dalamnya. 


\section{SIMPULAN}

Setiap negara tentunya memiliki kepentingan dan tujuan-tujuan kebijakan luar negeri yang harus dicapai demi kebutuhan warga negaranya, mulai dari tujuan untuk keamanan, otonomi, kesejahteraan atau kekayaan, dan status atau prestise. Begitupun dalam hal ini Korea Selatan. Namun pencapaian tujuan-tujuan tersebut tidak dapat dilakukan tanpa mempengaruhi perilaku dari negara lain, terutama mencegah aksi provokasi pihak asing.

Korea Selatan, dalam upaya untuk mempengaruhi perilaku Korea Utara dan mencegah aksi-aksi provokasinya melakukan sejumlah aksi dengan taktik persuasi, penawaran dan pemberian hadiah, ancaman hukuman, penalti hukuman non-kekerasan dan penggunaan kekerasan secara terbatas sepanjangan tahun 2008 hingga tahun 2010. Taktik persuasi, penawaran dan pemberian hadiah mendominasi di tahun 2008 dimana aksi provokasi Korea Utara pun nampaknya masih dipandang masih belum terlalu membahayakan atau level rendah. Akan tetapi memasuki tahun 2009, ketika Korea Utara melaksanakan provokasi nuklir, Korea Selatan pun mulai menunjukkan reaksi keras dengan melakukan taktik ancaman terhadap Korea Utara, namun disisi lain taktik persuasi dan penawaran serta pemberian hadiah pun tetap dilakukan untuk membujuk Korea Utara untuk menghentikan dan meninggalkan aksi-aksi provokasi, terutama nuklir, di masa depan.

Namun memasuki tahun 2010, aksi provokasi Korea Utara justru semakin meningkat dengan dilakukannya provokasi militer, penyerangan kapal Cheonan dan Pulau Yeonpyeong. Menghadapi aksi provokasi Korea Utara yang tidak dapat diubah dengan menggunakan taktik lain, Korea Selatan pun akhirnya menggunakan taktik penalti hukuman non-kekerasan, yakni dengan dikeluarkannya the May 24 Countermeasures against North Korea, yang didalamnya termasuk pula penggunaan secara terbatas taktik kekerasan atau militer, yakni latihan militer bersama US-ROK.

Dalam upayanya tersebut, Korea Selatan juga menggunakan sejumlah sumber daya yang ia miliki untuk mendukung kebijakannya atau memobilisasi aksi-aksinya dalam mencegah provokasi Korea Utara, mulai dari -utamanyakapabilitas ekonomi, militer dan jaringan diplomasi.

\section{DAFTAR PUSTAKA}

Anderson, J \& Jeffery A.L. (2013). Extended Deterrence and Allied Assurance: Key Concepts and Current Challenges for U.S. Policy. Dalam USAF Institute for National Security Studies Occasional Paper Vol. 69. Colorado: USAF. Diakses dari: <www.usafa.edu/df/inss/ OCP/OCP69.pdf> [23 Febuari 2015]

Astrom, A. (2013). The Korean Peninsula: Where the Cold War Never Ended: The Foreign Policy of the Republic Korea on a Peaceful Reunification with the Democratic People's Republic of Korea. Diakses dari: <www.diva-portal.org/ smash/get/diva2:634395/FULLTEXT01. pdf $>$ [6 November 2014]

Australia DFAT. (2014). Republic of Korea Country Brief. Australia Government Department of Foreign Affairs and Trade. Diakses dari: < http://dfat.gov.au/geo/ republic-of-korea/pages/republic-ofkorea-south-korea-country-brief.aspx> [13 Agustus 2015]

Brighi, E \& Hill, C. (2008). Implementation and Behaviour. Dalam Steve Smith, et.al. Foreign Policy: Theories, Actors and Cases. New York: Oxford University Press.

Bechtol, B.E. Jr. (2010). The Implications of the Cheonan Sinking: A Security Studies Perspective. International Journal of Korea Unification Studies. Diakses dari: <https://kinu.or.kr/eng/pub/pub 0301. jsp? bid $=$ DATA03... $>$ [5 November 2014]

Bush, J. (2014). South Korea. Oxford Economics. Diakses dari: www. oxfordeconomics.com/Media/Default/.../ SKORDB290114.pdf [26 Agustus 2015] BBC. 2010. North Korea 'trading nuclear technology'says UN panel. BBC News. Diakses dari: http://www.bbc. com/news/10180497 [26 Agustus 2015]

Chosunilbo. (2010). Int'l Experts Agree on Cheonan Findings. The Chosun Ilbo. Diakses dari: <http://english. chosun.com/site/data/html_ dir/2010/05/21/2010052100466.html> [12 Febuari 2015] 
Carlnaes, W. (2002). Foreign Policy. Dalam Hanbook of International Relations. Selected Reading, p. 430-452. London: SAGE Publications Ltd.

Cha, D.H . (2010). Lessons from the Cheonan Incident and South Korea's Response. Dalam The East Asian Institute Security Net Commentary No. 6 . Diakses dari: <www.eai.or.kr/data/ bbs/eng_report/201005271219030. pdf> [7 Maret 2015]

CIA. (2015). East and South East Asia: North Korea. The World Factbook. Diakses dari: < https://www.cia.gov/library/ publications/the-world-factbook/geos/ kn.html> [6 Juni 2015]

Cummings, B. (2004). North Korea: Another Country. Dalam Astrom, Alexander. 2013. The Korean Peninsula: Where the Cold War Never Ended: The Foreign Policy of the Republic Korea on a Peaceful Reunification with the Democratic People's Republic of Korea. Diakses dari: <www.diva-portal.org/ smash/get/diva2:634395/FULLTEXT01. pdf $>$ [6 November 2014]

Denmark, A.M. (2011). Proactive Deterrence: the Challenge of Escalation Control on the Korean Peninsula. Dalam Seri Paper Akademik Korean Ekonomic Institute. Diakses dari: < www.keia.org/sites/ default/files/.../proactive deterrence paper.pdfs [3 maret 2015]

Fazio, D. (2011). The Korean Security Threat: An Historical Context and Current Policy Options. Dalam ERAS edisi 12. Diakses dari: <artsonline. monash.edu.au/eras/files/2014/.../ dfazio.pdf> [3 Maret 2015]

Fisher, H. (2007). CRS Report for Congress: North Korea Provocative Actions 1950-2007. Diakses dari: https:// www.fas.org/sgp/crs/row/RL30004. pdf [13 Agustus 2015]

Holsti, K.J. (1995). International Politics: A Framework for Analysis. Seventh Edition. New Jersey: Prentice-Hall, Inc.

Holsti, K.J. (1967). International Politics: A Framework for Analysis. New Jersey: Prentice-Hall, Inc.
Hyun, A.K. (2004). Korea's Development under Park Chung Hee. Google Books. Diakses dari: https://books.google. co.id/books?id=loDCS-JEF78C\&pr intsec $=$ frontcover\&source $=\mathrm{gbs} \_\mathrm{ge}$ $\mathrm{cad}=0 \# \mathrm{v}=$ onepage $\& \mathrm{q}=$ peacefull $\% 20$ coexistence\&f=false [26 Agustus 2015]

Hassig, R.C. \& Kongdan O. (2003). North Korea: Harderst Nut. Dalam Astrom, Alexander. 2013. The Korean Peninsula: Where the Cold War Never Ended: The Foreign Policy of the Republic Korea on a Peaceful Reunification with the Democratic People's Republic of Korea. Diakses dari: <www.diva-portal.org/ smash/get/diva2:634395/FULLTEXT01. pdf $>$ [6 November 2014]

Institute for Unification Education. (2012). Understanding North Korea. ROK Ministry of Unification. Diakses dari: $<$ http://eng.unikorea.go.kr/content. do? cmsid=1820 $>$ [13 Agustus 2015]

Jervis, R. (1970). The Logic of Images in International Relations. New Jersey: Princeton University Press.

Jaquith, C. (2010). Washington, Seoul threaten N. Korea: S. Korea Gov't Impose Trade Sanctions. The Militan. Diakses dari: <http://www.themilitant. com/2010/7422/742201.html $>[12$ Febuari 2015]

Kirk, D. (2010). South Korea Dial Back Tough Talk Over Cheonan Sinking. The Christian Science Monitor. Diakses dari: $<$ http://www.csmonitor.com/World/ Asia-Pacific/2010/0531/South-Koreadials-back-tough-talk-over-Cheonansinking $>$ [12 Febuari 2015]

Kim H. (2013). Environment in Northeast Asia: Implication for South Korea. Dalam Weston S. Konishi. Rowing Together: Developing Parallel Paths to Stability, Denuclearization, and a Peace Regime on the Korean Peninsula. New York: Institute for Foreign Analysis, Inc.

Konishi, W.S. (2011). Denuclearizing North Korea: Exploring Multilateral Approaches to Riskn Reduction and Peace Regime Building. New York: Institute for Foreign Policy Analysis, Inc. 
Khamidov, A. (2008). The Lee Myung-bak Revolution: Explaining Continuity and Change in South Korea's Foreign Policy. Dalam SAIS U.S.-Korea Year book 2008 John Hopkins University. Selected Reading, p. 23-38. Diakses dari: $<$ uskoreainstitute. org/wp-content/uploads/2010/05/ Khamidov.pdf> [30 September 2014]

Kim, H.N. (2011). The Lee Government's Policy toward the Denuclearization of North Korea and its Implications for SouthNorth Korea Relations. International Journal of Korean Studies Vol. XV No. 2 Fall Edition. Diakses dari: <www. icks.org/publication/pdf/2011-FALLWINTER/4.pdf $>$ [10 Febuari 2015]

Lee, G. (2003). The Political Philosophy of Juche. Standford Journal of East Asian Affairs Vol. 3. Dalam Astrom, Alexander. 2013. The Korean Peninsula: Where the Cold War Never Ended: The Foreign Policy of the Republic Korea on a Peaceful Reunification with the Democratic People's Republic of Korea. Diakses dari: <www.diva-portal.org/ smash/get/diva2:634395/FULLTEXT01. pdf $>$ [6 November 2014]

MOU Special Office of Inter-Korean Dialogue.2009. South-North Dialogue in Korea: Fabuary 2008-December 2009. Ministry of Unification. Diakses dari:http://eng.unikorea.go.kr/content. do?cmsid=1821 [26 Agustus 2015]

Mosher, S.W. (1992). Korea in the1990s: Prospect of Unification. Dalam Astrom, Alexander. 2013. The Korean Peninsula: Where the Cold War Never Ended: The Foreign Policy of the Republic Korea on a Peaceful Reunification with the Democratic People's Republic of Korea. Diakses dari: <www.diva-portal.org/ smash/get/diva2:634395/FULLTEXT01. pdf $>$ [6 November 2014]

Office of the President. (2009). The Lee Myung Bak Administration's Foreign Policy and National Security Vision: Global Korea the National Security Strategy of the Republic of Korea. ROK Ministry of Unification. Diakses dari: <eng.unikorea.go.kr/cws board/board.do? mode $=$ download.. $>[13$ Agustus 2015]
Pomfret, J. (2010). South Korea to Halt All Trade with North Korea Over Sinking of Cheonan Warship. Washington Post. Diakses dari: <http://www.washingtonpost.com/ wp-dyn/content/article/2010/05/23/ AR2010052301712.html> [12 Febuari 2015]

PSI-online. (2015). Proliferation Security Initiative: Who are we? Diakses dari: http://www.psi-online.info/Vertretung/ psi/en/01-about-psi/0-about-us.html [5 September 2015]

Richburg, K.B. (2010). South Korean President Takes Responsibility for Failing to Protect Country, Signals Hardened Military Stance toward North. Washington Post. Diakses dari: <http://www.washingtonpost.com/ wp-dyn/content/article/2010/11/28/ AR2010112804537.html? wpisrc $=$ nl headline $>$ [12 Febuari 2015]

ROK Ccourth. (1987). The Constitution of the Republic of Korea. Diakses dari: <english.ccourt.go.kr/.../eng/.../ Constitution_of_the_Republic_of_ Korea.p...> [13 agustus 2015]

ROK Ministry of Defense. (2010). ROK Defense White Paper. Diakses dari: $<$ http://www.mnd.go.kr/cop/pblictn/ selectPublicationUser.do?siteId $=$ mnd ionSeq $=583 \&$ pageIndex $=1 \&$ id $=$ mnd eng_021400000000> [29 Januari 2015]

ROKMOFA.(2010). KoreaRefers the Cheonan Issue to the Security Council. ROK Ministry of Foreign Affairs. Diakses dari: $<$ http://www.mofa.go.kr/webmodule/ htsboard/template/read/engreadboard. pagenum $=1 \&$ tableName $=$ TYPE $\mathrm{pc}=\& \mathrm{dc}=\& \mathrm{wc}=\& l \mathrm{u}=\& \mathrm{vu}=\& i \mathrm{u}=\& \mathrm{du}=$ $>$ [12 Febuari 2015]

ROK MOFA. (2008). ROK Diplomatic White Paper 2008. Diakses dari: <http://www. mofa.go.kr/ENG/policy/whitepaper/ index.jsp?menu=m_20_160 $>$ [1 Agustus 2015]

ROK MOFA. (2011). ROK Diplomatic White Paper 2011. Diakses dari: < http://www. mofa.go.kr/ENG/policy/whitepaper/ index.jsp?menu=m_20_160 $>$ [1 Agustus 2015] 
ROKMOU.(2012).TheRepublicofKorea's Policy toward North Korea. ROK MOUBrochure. Diakses dari: <http://eng.unikorea.go.kr/ content.ode $=$ view\&page $=\&$ cid $=32794>$ [10 Febuari 2015]

ROK MOU. (2010). White Paper on Korean Unification. Diakses dari: < http://eng. unikorea.go.kr/content.do? cmsid=1819> [31 Juli 2015]

ROK MOU. (2013). Unification Policy in preparation for unified Korea: Lee Administration's North KoreaPolicy20082012). ROK MOU Brochure. Diakses dari: < http://eng.unikorea.go.kr/content. mode $=$ view $\&$ page $=\&$ cid $=32798>[3$ Agustus 2015]

ROK MOU. (2015). Korean National Unification Formula. Diakses dari: $<$ http://eng.unikorea.go.kr/content. do?cmsid=1786 $>$ [13 Agustus 2015]

Stake, R.E. (2010). Qualitative Research: Studying How Things Work. New York: The Guilford Press.

Savada, A.Mand Shaw, W. (editor). (1990). South Korea: A Country Study. Countrystudies. us. Diakses dari: < http://countrystudies. us/south-korea/27.htm $>\quad[13$ agustus 2015]

The Financial Times. (2009). Transcript: FT interview with Lee Myung Bak. Diakses dari: http://www.ft.com/intl/ cms/s/0/b199dc66-1c43-11de-977c00144feabdc0.html\#axzz311 eM7O71 [26 Agustus 2015]

The International Institute of Strategic Studies. (2013). Military Balance 2013. Diakses dari: $<$ http://www.iiss.org/en/publications/ military\%20balance/issues/the-militarybalance-2013-2003/mb2013-06-asiab6cf $>$ [7 September 2015]

Wallace, R.D. (2014). The Determinants of Conflict: North Korea's Foreign Policy Choices 1960-2011. Diakses dari: <https:// krex.k-state.edu/dspace/bitstream/.../ RobertWallace2014.pdf?...1>

Yonhap. (2010). S. Korean Navy Ship Sinking in Yellow Sea: Officials. Yonhap News Agency. Diakses dari: <http://english. yonhapnews.co.kr/nal/2010/03/27/13/ 0301000000AEN2010032700010031 5F.HTML $>$ [12 Febuari 2015] 